\title{
ADVANCED POLICE METHODS IN BERKELEY
}

\author{
BY HAROLD G. SCHUTT \\ National Institute of Public Administration
}

High-grade policemen, one-third of them college graduates, plus an appropriate utilization of their brains, have made Berkeley's police force famous and their chief the president of the Association of Chiefs of Police. $\quad:: \quad:: \quad:: \quad:: \quad:: \quad:: \quad$ :: $\quad$ ::

Berkeley, California, has in recent years attracted considerable attention because of the excellence of its police department. Attention for such a reason is rather unusual. There are several features about the Berkeley department that are different from those found in the ordinary department. For example, all the patrolmen do most of their patrolling in automobiles, and one of those gentlemen possesses that title so much affected by college professors-doctor of philosophy. Since police work is so largely a matter of personnel, it may be well to discuss that subject first.

Speaking of personnel, it has been the writer's observation that most people think of the Berkeley Police Department and Mr. August Vollmer as synonymous. Mr. Vollmer was elected marshal of the city in 1905 when the department consisted of a "desk, a broken chair and three assistants," and has been its chief since that time although the type of government has changed. To him belongs the credit for the development of scientific police methods as they are practiced in Berkeley. Berkeley now operates under a commission government charter, but the greatest virtue of the commissioner of public health and safety, as far as police is concerned, is his non-interference with the policies of the chief.
The first point in personnel is selection. The chief exercises full control of hiring and discharging, there being no civil service provisions applying to the department. He chooses his men largely by means of mental examinations, using tests like those given in the army to determine a candidate's intelligence. Considerable emphasis is placed upon the a plicant's reason for joining the force. Mr. Vollmer wants men who are $l_{1}$ ' 'ing forward to a career in police service. One result has been that instead of getting taxi drivers and mechanics he has secured thirteen university-educated men for his police force of thirty-three men. The chief believes that for every time a policeman is called upon to use his brawn his brain is needed a thousand times. Consequently high intelligence has been deemed more important than mere physical health.

\section{UTILIZING GOOD BRAINS}

Having secured university men for cops does not, however, make a police department. They probably do not know any more, if as much, about police work as a taxicab driver, but they do have greater ability to learn. Herein enters the Berkeley police training school. Mr. Fosdick, in "American Police Systems," says that it is the most ambitious that has been attempted 
in America. ${ }^{1}$ The course extends over a period of three years, the first year courses being-physics; chemistry, physiology and anatomy; criminology, anthropology and heredity; and toxicology. The second year surely requires a college education-criminal psychology; psychiatry; criminology, theoretical and applied; police organization and administration; police methods and procedure. The third year completes the course with microbiology and parasitology; police microanalysis; public health, first aid to the injured; elementary and criminal law. A large part of the instruction is given by Mr. Vollmer and Dr. Albert Schneider, who has the title of dean of the school. Dr. J. D. Ball, a psychiatrist of Oakland, Mr. E. O. Heinrich, an examiner of questioned documents of San Francisco, the city attorney and others give considerable instruction. Except for the first two mentioned this work has been gratuitous. Dr. Schneider, who is connected with the University of California, receives a small compensation for his work. ${ }^{2}$

When a new man enters the department he is given some individual training to enable him to do fairly good patrolling and then he takes the training school work as it is given. The courses occupy from one to five or more hours per week. Every Friday at four o'clock the whole department, with the exception of a skeleton force which is kept on duty, meets for one hour. The men call this the "crab club." At this weekly meeting the chief explains any of his orders, the reasons for which are not clear to the men, the men make suggestions that have occurred to them

\footnotetext{
${ }^{1}$ Fosdick, "American Police Systems," p. 299.

2 The article in the Journal of the American Institute of Criminal Law and Criminology for March 1917, written by Mr. Vollmer and Dr. Schneider, further describes the training school, and is practically up to date.
}

and voice their complaints if they have any. Chief Vollmer feels that this discussion does much to develop team. play in the department. If there is nothing else to occupy the hour a lecture is given. Not long ago a professional safe-blower explained the technique of his trade and other crooks have given first-hand information as. to the methods used by criminals.

Mention should also be made of the courses in criminology that are given during the summer session of the University of California, which is located at Berkeley. There has been very close co-operation between the police and the university. This past summer Mr. Vollmer, Mr. Heinrich and Dr. Ball have given four courses in criminology. When possible, recruits to the police departments take these courses.

\section{AUTOMOBILE PATROLS}

As has been said, the newcomer, while taking the training school work, has also been patrolling and instead of walking about getting flat feet he has been patrolling de luxe. Each patrolman furnishes his own automobile and is allowed thirty dollars a month in addition to his salary. The department furnishes gasoline and oil not only for his official duties but also for any pleasure driving that he may do. The average distance traveled by each car is over a thousand miles per month, which for Berkeley's twenty patrolmen amounts to about two hundred and fifty thousand miles in a year. Berkeley is a city of sixty thousand people covering a compact area of nine square miles. It is largely residential, the business center being small, due to the proximity of Oakland and San Francisco. There is a growing industrial section along the bay shore. For patrolling this type of city, autos seem to have been very successful. 
One of the things that Chief Vollmer has tried to obtain has been constant touch between headquarters and the man on duty on the street. This is obtained by means of red flashing lights located at the principal corners about the city and where each one would be most readily seen by the patrolman driving his car. By means of switches at the sergeant's desk he can flash these lights and call a patrolman to a box, and in this way give any orders that are necessary. Since these lights are not so clearly visible in the daytime twenty-five horns have been installed. These are used during the day for emergency purposes. If the need of the officer is not urgent the lights are used, as persons living near one of the horns have found the noise objectionable. They sound like lowpitched automobile horns. These devices have made it possible to reach a policeman on his beat in two or three minutes at the most and send him where he may be needed. But this has not satisfied the desire for progress. Experiments have been made in equipping the police cars with wireless telephones which could be in constant contact with the police station. Certain technical difficulties have arisen, but they are on a fair way to being overcome.

The patrolman in Berkeley has considerable discretion in covering his district. $\mathrm{He}$ is held responsible for conditions there and he can use his own judgment in many ways as to how he shall police it. The sergeant remains at the station most of the time, where he can direct his men when necessary when they call in hourly, or by means of the signal system. $\mathrm{He}$ occasionally drives out on a tour of inspection. The ambulance and emergency wagon are handled by two men in the record room who have time for answering the calls that come in.

\section{RECORDS THAT HELP}

Another feature of which Berkeley can be justly proud is the record system. The complaints as they come in are entered on cards and filed by serial number. The reports of the officers assigned to the case are attached to the original card and filed with it. If a case has not been closed a metal tag is attached to the card and the case is watched until the officer in charge has completed the investigation and satisfactory reports have been made. One cause for the success of the Berkeley department and the high esteem in which it is held in the community is the thoroughness with which complaints are treated. These cards are indexed according to person making complaint, crime complained of and person mentioned in complaint. There are now some sixty-six thousa? in these records on file-a history o: he department since 1905.

A modus operandi sheet is filled out for each complaint involving theft, fraud, property taken by violence, or where an entry has been made to commit burglary. This may not mean much to a layman, but many criminals have a particular method of performing and a record of the method used in crimes committed helps to apprehend the offender.

The finger-print file contains sixty thousand prints properly classified. Berkeley maintains exchanges with about twenty-five cities and institutions, so that the identification files are constantly growing. There are twenty-seven thousand Bertillon measurement records and twenty thousand English circulars. The picture gallery contains almost as many pictures.

The criminal index file is very complete and is used to index the different identification files. It contains cards giving name (filed also under each 
alias), criminal record, description and reference to the finger print, Bertillon or other files. When cards are made for this file a duplicate is made and is filed under the crime committed.

There is also a stolen property file in which different colored cards are used to indicate different classes or articles. They are filed according to distinguishing number or initial when possible.

From the records certain interesting pin maps have been made. One shows the distribution about the city of the different classes of crime; others show the same thing for each of the three details. If the chief knows what crimes are committed, where and when, it is easier to prevent crime or to apprehend the criminal. Another map shows casualties and their nature. Still another, which will be discussed later, is that showing juvenile delinquencies.

The superintendent of records is a handwriting expert and is so recognized throughout the United States. One of the clerks is a finger-print expert; in fact specialization exists throughout the department. Mr. Larson, the Ph.D. who has been mentioned, has made two contributions to finger-print research regarding racial characteristics of finger prints and transmission from generation to generation of finger-print types. $\mathrm{He}$ has also prepared a paper on the use of the sphygnomanometer, or blood pressure apparatus in police work. This devise registers the regularity and intensity of the heart beats and of breathing. It has been found that when questions are put to a suspected person the regularity of the heart and breathing, over which the person has no conscious control, indicates whether the truth is being told or not. Incidentally this apparatus was used recently in a case of theft at the university. A girl under suspicion was cleared and another who was not suspected was easily detected. Had the guilty person not been found it is difficult to say what stain might have attached to the reputation of the girl who was generally suspected, and her college career might have been made most unpleasant.

The use of the camera in police work has also been developed in Berkeley. This is especially true in connection with the microscope. While the writer was in Berkeley he saw some photographs of human hairs that were so much enlarged and were so plain that within certain limits the age of the hair and whether it was from a male or female could be told.

\section{THE PREVENTIVE WORK}

We now come to the other and more important police function - crime prevention. Some crime has been prevented because professional criminals know that the police are efficient and so do not operate there. But something more positive than that has been done by educating the public to believe in the police so that when they see something suspicious they report it. This education has been secured largely by developing more contacts between police and public. Chief Vollmer has spoken at meetings of almost every organization in Berkeley - Church, social and business clubs, university classes, American Legion, fraternities, Y. M. C. A. It has now become a habit for a citizen, or more likely a citizeness, to call in the police for the most minor matters. Since the department, like an automobile agency, says "service is our motto," it is glad to get these calls and they make for a better understanding between all concerned.

Chief Vollmer for the same reason has a high regard for junior police. He told the writer that "some of the boys, former members of our old junior 
police organization and now prominent men in the community, are among our greatest boosters and contribute to the welfare of the department in various ways." At present the boy scout organization is very strong in Berkeley and most of the junior police work is carried on through it. Mr. Vollmer endeavors to meet with the scouts once a month and talk to them. To be successful, he believes that junior police or boy scouts must have able leadership.

A map showing juvenile delinquency has already been mentioned. By means of beads and pins of different colors the location of cases of delinquency, low intelligence, truancy, and miscellaneous juvenile offenses is shown for both boys and girls. The data to make this map is secured from school reports. By watching these minors it is possible to prevent them from developing into criminals as they grow older. As in the case with junior police it is the policy of the police to get in touch with the citizens of the future while they are still young, to help correct any deficiencies that may exist and try to make good Americans of them.

As may be surmised, when minors come into the hands of the police, effort is made to find cause that led the boy or girl astray and to remedy the condition, making punishment for the offense committed a secondary matter. Not long ago four boys, ranging in age from eleven to sixteen years, were in trouble for stealing. One was somewhat feeble-minded, but the others were mentally strong. They had become sex offenders and unless something was done the boys would very likely turn out badly. By co-operation with the boys' parents the conditions which had led them into bad practices were changed and the future is promising both for the boys and for society.

Such is the nature of the police work in Berkeley. That it has been suc- cessful is shown by the fact that the number of crimes committed has grown but little in recent years in spite of the growth of population and a crime wave that is supposed to be sweeping over the country. In 1911 there were ninety-eight cases of first degree burglary, in 1915 there were eighty-six, and in 1920 there were one hundred and twenty-three. For petit larceny for the same years the figures were three hundred and ten, four hundred and fifty-one, and four hundred and sixtynine. Another proof that Berkeley methods have something to do with crime prevention is that there was a sharp upward trend in the number of crimes committed after several men left the department to join the military service when the United States entered the war. This con ${ }^{\text {ition }}$ continued until the new men $w^{*}$ trained.

\section{costs}

The Berkeley patrolmen receive one hundred and forty dollars per month in addition to the thirty dollars that they receive for their car upkeep. Clerks receive the same salary as patrolmen except that they do not have cars. Sergeants receive one hundred and sixty dollars per month and twenty dollars for car upkeep. Detectives receive one hundred and seventy dollars as salary and twentyfive dollars for car upkeep. The superintendent of records receives two hundred and twenty dollars, and the chief of police receives three hundred dollars. The total budget for the present year is eighty-five thousand dollars, or about a dollar and forty-two cents for each resident of the city.

The writer, speaking with several persons who were interested in police work in large cities, expressed doubt whether methods such as are used in Berkeley would be workable in the 
large cities. When one stops to consider that the greater part of most large cities is residential and that Berkeley might be considered a precinct in the great metropolitan area surrounding San Francisco, one wonders if the large city cannot learn from the Pacific Coast city. However, some one has said that the mediumsized city is the present American municipal problem and here conditions are not so different from those existing in Berkeley. That one city of a hundred thousand people sees promise of help is shown by the fact that this last summer the chief of police of Tacoma, Washington, and four other officers from that department spent several weeks in Berkeley taking the courses in criminology at the university and studying the methods of the local police department.

That Chief Vollmer's efforts have not been entirely unappreciated may be indicated when it is said that his salary this year received an unsolicited increase and that at the last convention held in St. Louis in June he was elected president of the International Association of Chiefs of Police.

\section{PETERS OF BOSTON}

\section{A REFORM MAYOR WHO DID NOT FAIL}

\section{BY W. B. MUNRO}

Roscoe Conkung ance remarked that when Dr. Johnson spoke of "patriotism" as the last refuge of the scoundrel he ignored the vast possibilities which are latent in the word "reform." Conkling was not alone in his dislike of the term. Theodore Roosevelt defined it as something with a "lunatic fringe" attached, and Brand Whitlock later paid left-handed homage to reformers by defining them as a group of men and women who feel a solemn responsibility "for the shortcomings of others."

At any rate there is a widespread belief that a municipal "reform" administration is bound to be a disappointment, even to its own supporters, because it promises more than it can perform, and goes out of office after a single term leaving a trail of popular resentment in its wake. Too often, it is true, this has been the record of the strictly honest man in municipal office. But it is not always so. The experience of the past decade, in more than one of our great communities, has demonstrated the fact that a municipal administration can be efficient and honest without being impractical or becoming unpopular. It is well that such achievements be made known. They give courage to the faint in the long battle for civic decency.

Andrew J. Peters was inaugurated mayor of Boston in February, 1918. His record as a member of congress and as assistant secretary of the treasury warranted the expectation that he would prove to be one of the best mayors in the city's history, and this expectation, during the past four years, he has entirely fulfilled. The Boston city charter renders the mayor ineligible for immediate re-election; had it not been for this obstacle Mr. Peters would probably have been pressed into service for another four years. Setting out with no lavish array of promises, and attempting no wholesale reconstruction of the city's public affairs, he has none the less attained the chief 